\begin{tabular}{|l|l|l||}
\hline \multicolumn{2}{|c|}{ PublisherInfo } \\
\hline \hline PublisherName & $:$ & BioMed Central \\
\hline \hline PublisherLocation & $:$ & London \\
\hline \hline PublisherImprintName & $:$ & BioMed Central \\
\hline \hline
\end{tabular}

\title{
Gypsy at the periphery
}

\begin{tabular}{|l|l|l||}
\hline \multicolumn{2}{|c|}{ ArticleInfo } \\
\hline \hline ArticleID & $:$ & 3853 \\
\hline \hline ArticleDOI & $:$ & $10.1186 /$ gb-spotlight-20001207-01 \\
\hline \hline ArticleCitationID & $:$ & spotlight-20001207-01 \\
\hline \hline ArticleSequenceNumber & $:$ & 290 \\
\hline \hline ArticleCategory & $:$ & Research news \\
\hline \hline ArticleFirstPage & $:$ & 1 \\
\hline \hline ArticleLastPage & $:$ & 2 \\
\hline \hline & & RegistrationDate : 2000-12-07 \\
ArticleHistory & $:$ & OnlineDate $\quad$ 2000-12-07 \\
\hline \hline ArticleCopyright & $:$ & BioMed Central Ltd2000 \\
\hline \hline ArticleGrants & $:$ & \\
\hline \hline ArticleContext & $:$ & 130591111 \\
\hline \hline
\end{tabular}




\section{Jonathan Weitzman}

Email: jonathanweitzman@hotmail.com

Chromatin insulators protect genomic domains from chromosomal position effects and from enhancer activation, but the mechanisms by which the insulators function are largely unknown. In the November Molecular Cell Gerasimova et al. provide insights by analyzing the behavior of the gypsy insulator in diploid interphasic cells from Drosophila imaginal disks (Mol Cell 2000, 6:1025-1035). They employed three-dimensional constructions of immunofluorescence microscopy images to investigate the nuclear localization of the gypsy element and its associated proteins su(Hw) and $\bmod (\operatorname{mdg} 4)$. The insulator proteins are localized within about 21 discrete 'insulator bodies', which are found at the nuclear periphery. The gypsy sequence was able to direct the clustering of DNA to these peripheral sites. The functional significance of the nuclear aggregates was investigated by observing the effect of heat-shock treatment. Heat shock induced disruption of gypsy insulator bodies, changes in nuclear DNA distribution and increases in global gene expression. These observations suggest that insulators can regulate gene expression by controlling the nuclear organization of chromatin fibres.

\section{References}

1. The role of insulator elements in defining domains of gene expression.

2. Molecular Cell, [http://www.molecule.org/]

3. Polycomb and trithorax group proteins mediate the function of a chromatin insulator. 